SŁAWOMIR ZWOLAK*

\title{
ZASADY PRAWA BUDOWLANEGO
}

\section{Wprowadzenie}

Zagadnienie zasad prawa budowlanego sugeruje, że tematyka niniejszego opracowania, będzie dotyczyć obszaru prawa budowlanego, związanego z działalnością budowlaną podmiotów, które w działalności tej uczestniczą. Zacząć wypada, że pojęcie prawa budowlanego nie jest jednoznaczne, gdyż obejmuje nie tylko ustawę z dnia 7 lipca 1994 r. - Prawo budowlane ${ }^{1}$, ściślej jego normy prawne, ale także inne normy prawne, dotyczące procesu budowlanego, a przede wszystkim przepisy ustawy z dnia 27 marca 2003 r. o planowaniu i zagospodarowaniu przestrzennym², ustawy z dnia 27 kwietnia 2001 r. - Prawo ochrony środowiska ${ }^{3}$ czy przepisy ustawy z dnia 21 sierpnia 1997 r. o gospodarce nieruchomościami $^{4}$. Dlatego też ogólnym pojęciem prawa budowlanego rozumie się całokształt przepisów prawnych związanych z dziedziną budownictwa ${ }^{5}$. Taki zakres prawa budowlanego jest więc szerszy od dość potocznie przy-

* Dr, absolwent Wydziału Prawa, Prawa Kanonicznego i Administracji Katolickiego Uniwersytetu Lubelskiego Jana Pawła II; sla_z@poczta.fm

${ }^{1}$ Ustawa z dnia 7 lipca 1994 r. - Prawo budowlane, tekst jednolity, Dz. U. z 2016 r., poz. 290 z późn. zm.

${ }^{2}$ Ustawa z dnia 27 marca 2003 r. o planowaniu i zagospodarowaniu przestrzennym, tekst jednolity, Dz. U. z 2016 r. poz. 778 z późn. zm.

${ }^{3}$ Ustawa z dnia 27 kwietnia 2001 r. - Prawo ochrony środowiska, tekst jednolity, Dz. U. z 2016 r., poz. 672 z późn. zm.

${ }^{4}$ Ustawa z dnia 21 sierpnia 1997 r. o gospodarce nieruchomościami, tekst jednolity, Dz. U. z 2016 r., poz., 2147.

5 T. Biliński, E. Kucharczyk, Prawo budowlane z omówieniem i komentarzem, Zielona Góra 2013, s. 43. 
jętych określeń zakresu tego prawa jako jednakowego niemal z zakresem ustawy Prawo budowlane. Takie podejście może być jedynie użyteczne dla zbadania interakcji jakie występują w oddziaływaniu norm należących do różnych aktów prawnych. Jednakże dla celów poznawczych i interpretacyjnych niniejszego opracowania, skupię się przede wszystkim na regulacji ustawy Prawo budowlane.

Zasady prawa w znaczeniu dyrektywalnym, to takie normy prawne, którym przypisuje się charakter fundamentalny. Zasady prawa odgrywają w każdym systemie prawa rolę szczególnie doniosłą. Po pierwsze, przy tworzeniu prawa ukierunkowuja bowiem działania legislatorów, wskazując jakie stany rzeczy mają być celem ich poczynań, jakie wartości powinni respektować i chronić przed naruszeniami. Po drugie, zasady prawa kształtują wykładnię prawa. Po trzecie, wskazują kierunki stosowania prawa, w szczególności sposoby czynienia użytku z tzw. luzów decyzyjnych ${ }^{6}$. Ponadto zasady prawa mają swoje znaczenie $\mathrm{w}$ naukowej analizie. Tak określone role zasad prawa przyczyniają się do uporządkowania norm prawnych kształtujących dane instytucje oraz do zharmonizowania procesów wykładni przepisów i stosowania prawa. Zatem istotną ich funkcją jest harmonizowanie porządku prawnego oraz zapewnienie jego spójności ${ }^{7}$. W szczególności w świetle zasad prawa można łatwiej odczytać intencje konkretnego unormowania (ratio legis), zaś reguły wykładni systemowej nakazują przypisanie interpretowanemu przepisowi takiego znaczenia, jakie uznać można za najbardziej zgodne z zasadami prawa ${ }^{8}$. To ostatecznie pozwala nawet mówić o swoistej nadrzędności zasad prawa nad zwykłymi normami prawnym.

Poza zasadami prawa, mającymi ogólne znaczenie dla regulacji prawnych, poszczególne ich gałęzie, a także działy, wykształciły własne zasady, właściwe tylko dla danego obszaru prawa. Dlatego można mówić o zasadach prawa budowlanego, które stanowią realizację zadań i związaną z tym rozmaitością chronionych wartości przez przepisy ustawy - Prawo budowlane. A zatem można dokonać próby zdefiniowania zasad prawa budowlanego jako najbardziej podstawowych rozstrzygnięć pochodzących od ustawodawcy, zawierających kwalifikowane treści ${ }^{9}$. Rozstrzygnięcia te określają dyrektywy postępowania, jakimi powinni

${ }^{6}$ S. Wronkowska, M. Zieliński, Z. Ziembiński, Zasady prawa. Zagadnienia podstawowe, Warszawa 1974, s. 188.

7 Tamże, s. 188.

${ }^{8}$ L. Leszczyński, G. Maroń, Pojęcie i treść zasad prawa oraz generalnych klauzul odsyłajacych. Uwagi porównawcze, "Annales UMCS sectio G” 2013, vol. LX, 1, s. 81-82.

9 Z. Witkowski, [w:] Z. Witkowski (red.), Prawo konstytucyjne, Toruń 2006, s. 67. 
kierować się uczestnicy procesu budowlanego. Charakteryzują one również istotę Prawa budowlanego, przyjmując charakter reglamentacyjny, zawierający nakazy i zakazy typu policyjnego, podyktowane interesem publicznym, a zwłaszcza potrzebą ochrony pewnych dóbr takich jak: bezpieczeństwo, zapewnienie odpowiednich warunków zdrowotnych, higienicznych, ochrony środowiska itp.

Dokonując wnikliwej analizy ustawy Prawo budowlane, można stwierdzić, istnienie poszczególnych zasad, które emanują na wykładnie wszystkich pozostałych przepisów o charakterze szczegółowym, odnoszących się do całego procesu budowlanego. Przyjmując taką konstatację, należy wywnioskować z interpretacji norm prawnych, ogólne zasady odnoszące się do postulatów, które w ujęciu dyrektywalnym wyrażają z reguły wartości, które ustawodawca uważa za szczególnie doniosłe stosując normy prawa budowlanego. Zasady prawa budowlanego stanowią stały punkt odniesienia do szeroko rozumianego procesu budowlanego, objętego zakresem przedmiotowym całej regulacji, czyli etapów projektowania, budowy, użytkowania i rozbiórki obiektu budowlanego. Zawierają istotne wskazówki dla procesu interpretowania i stosowania, które należy jakby „wyjąć przed nawias” w ustawie, wyróżniając je w ten sposób przed normami szczegółowymi.

W obowiązującej ustawie Prawo budowlane, można wyodrębnić takie zasady jak: zasada wolności budowlanej, zasada poszanowania interesów osób trzecich, zasada ochrony interesów osób niepełnosprawnych, zasada ochrony zabytków, zasada projektowania i budowania obiektów budowlanych, zasada prawidłowego użytkowania obiektów budowlanych, zasada właściwego utrzymania obiektów budowlany, zasada racjonalnego użytkowania energii, zasada wiedzy technicznej ${ }^{10}$. Katalog powyższych zasad nie jest katalogiem zamkniętym i obejmuje zasady w niejednakowym stopniu ustabilizowane i bezdyskusyjne. Podejmując próbę ich omówienia oraz systematyzacji według stopnia doniosłości, należy stwierdzić, że podstawową zasadą dla całego procesu budowlanego, która przeważa nad pozostałymi zasadami, jest zasada wolności budowlanej.

${ }^{10}$ Na pytanie, w jakich przypadkach realizować daną zasadę, odpowiedź nieodmiennie wydaje się taka sama: „we wszystkich w których ta zasada może mieć charakter relewantny dla podejmowanej decyzji". M. Kordela, Zasady prawa jako normatywna postać wartości, „Ruch Prawniczy, Socjologiczny i Ekonomiczny” 2006, nr 1, s. 47. 


\section{Zasada wolności budowlanej}

Zasada wolności budowlanej należy do podstawowych zasad prawa budowlanego. Jej normatywnym wyrazem obowiązywania jest treść art. 4 ustawy - Prawo budowlane mówiący, że każdy ma prawo zabudowy nieruchomości gruntowej, jeżeli wykaże prawo do dysponowania nieruchomością na cele budowlane, pod warunkiem zgodności zamierzenia budowlanego z przepisami ${ }^{11}$. Znaczenie tej zasady dla jednostki jest oczywiste, gdyż służy ona ochronie podmiotów zaangażowanych w procesy budowlane ${ }^{12}$. W literaturze podnosi się, że wolność budowlana jest nie tylko zasadą prawa, ale także publicznym prawem podmiotowym o charakterze wolnościowym. Konstytucja Rzeczypospolitej Polskiej ${ }^{13}$, odnosząc się do własności, w szczególności w art. 21 i 64, kreuje jednocześnie zasadę ustrojową i konstytucyjne prawo podmiotowe, a wolność budowlana stanowi element składowy konstytucyjnego prawa podmiotowego jako prawa własności ${ }^{14}$. Treść tego prawa stanowi bowiem pewien szczególny przykład korzystania z rzeczy. Dotyczy też charakteru uprawnień zawartych w prawie własności, gdyż właścicielowi przysługuje nie tylko ochrona i swoboda kształtowania swoich uprawnień w sferze stosunków cywilnoprawnych, ale również ochrona praw i możliwości kierowania roszczeń wobec władzy publicznej, zarówno w sferze prywatnoprawnej, jak i publicznoprawnej ${ }^{15}$. Mając na uwadze stanowisko doktryny prawa, mówiące, że istota zasady wolności budowlanej wynika z potrzeby za-

11 Z. Kostka, zwraca uwagę na niekonsekwentne ujęcie art. 4 ustawy - Prawo budowlane. Jak twierdzi przepis zawiera deklarację wolności zabudowy, która nie wiedzieć dlaczego ogranicza się tylko do zabudowy nieruchomości gruntowej, pomijając wykonywanie robót budowlanych na pozostałych nieruchomościach znanych polskiemu systemowi prawnemu, mianowicie w lokalach i budynkach stanowiących na podstawie szczególnych przepisów odrębne od gruntu przedmioty własności. Z. Kostka, Prawo budowlane. Komentarz, Gdańsk 2005, s. 23.

12 Z. Leoński, Zasada wolności budowlanej i jej administracyjnoprawne ograniczenia, [w:] Z. Leoński (red.), Rola materialnego prawa administracyjnego a ochrona praw jednostki, Poznań 1998, s. 141.

${ }^{13}$ Konstytucja Rzeczypospolitej Polskiej z dnia 2 kwietnia 1997 r., Dz. U. Nr 78, poz. 483, z późn. zm; dalej jako: Konstytucja RP.

${ }_{14}$ Jak zauważył NSA, zasada swobody budowlanej, stanowi rozwinięcie na gruncie prawa budowlanego konstytucyjnej zasady ochrony własności (art. 21 ust. 1 i art. 64 ust. 3 Konstytucji RP). Wyrok NSA z 23 lutego 2007 r., II OSK 354/06, LEX nr 505624; Wyrok NSA z 18 stycznia 2008 r., II OSK 1876/06, LEX nr 508458.

15 R. Hauser, Z. Niewiadomski, Konstytucyjne aspekty regulacji procesu inwestycyjno-budowlanego, „Państwo i Prawo” 2015, nr 6, s. 3. 
pewnienia konstytucyjnej ochrony prawa własności ${ }^{16}$, należy przyjacć, że treścią zasady wolności budowlanej jest prawny nakaz poszanowania wolności i własności oraz uznania, że przepisy prawa budowlanego ograniczają potencjalny zakres inwestora wynikający z wolności budowlanej oraz prawa własności ${ }^{17}$. Zasada wolności budowlanej stanowi zatem filar procesu inwestycyjno-budowlanego, która powinna być uznana za nakaz skierowany do organów stosujących prawo, które powinny dążyć do zapewnienia jak najszerszego zakresu tej wolności ${ }^{18}$. Zasada ta jest w końcu prawną gwarancją uchylenia prewencyjnego zakazu wykonywania robót budowlanych, podstawą do właściwego ujęcia istoty publicznego prawa podmiotowego ${ }^{19}$.

\section{Zasada poszanowania interesów osób trzecich}

Przepisy ustawy Prawo budowlane wprowadzają zasadę nakazującą poszanowanie, występujących w obszarze oddziaływania obiektu, uzasadnionych interesów osób trzecich, w tym zapewnienie dostępu do drogi publicznej. Zakres ochrony interesów osób trzecich wynika z interesu prawnego, dotykającego kwestie oddziaływania jednej nieruchomości na inne sąsiednie ${ }^{20}$. Ochrona uzasadnionego interesu osób trzecich winna uwzględniać obowiązek równego traktowania stron, wyrażającą

${ }_{16}$ Z. Leoński, Zasada wolności budowlanej i jej administracyjnoprawne ograniczenia, [w:] H. Bauer, R. Hendler, P. M. Huber, B. Popowska, T. Rabska, M. Szewczyk (kom. red.), Kierunki rozwoju prawa administracyjnego. Podstawowe zagadnienia prawa budowlanego i planowania przestrzennego. Dziesiąte Niemiecko-Polskie kolokwium prawników administratywistów. Poznań 8-12 września 1997 r. Referaty i głosy w dyskusji, Poznań 1999, s. 362; Z. Leoński, Materialne prawo administracyjne, Warszawa 2005, s. 120; Z. Leoński, Zasada wolności..., [w:] Z. Leoński (red.), Rola materialnego..., s. 141; W. Jakimowicz, Konstrukcja i istota wolnościowego prawa do zabudowy, "Samorząd Terytorialny" 2005, nr 6, s. 47; D. Sypniewski, Deregulacja procesu inwestycyjno-budowlanego. Ograniczenie reglamentacji robót budowlanych, Przegląd Prawa Publicznego 2013, nr 2, s. 76; Z. Czarnik, Miejscowy plan zagospodarowania przestrzennego jako podstawa wykonywania wtasności nieruchomości, "Zeszyty Naukowe Sądownictwa Administracyjnego" 2006, nr 2, s. 44; B. Majchrzak, Procedura zgłoszenia robót budowlanych, Warszawa 2008, s. 27.

17 Z. Leoński, M. Szewczyk, M. Kruś, Prawo zagospodarowania przestrzeni, Warszawa 2012, s. 252.

${ }^{18}$ S. Zwolak, O wolności budowlanej w orzeczeniu polskiego Trybunału Konstytucyjnego w sprawie pozwolenia na budowę (Kp 7/09), "Ius et Administratio” 2014, nr 2, s. 76.

${ }_{19}$ Z. Leoński, M. Szewczyk, M. Kruś, Prawo zagospodarowania..., s. 353.

${ }^{20}$ Wyrok WSA w Warszawie z 3 czerwca 2004 r., IV/SA 1688/02, LEX nr 704413. 
się tym, że właściciel nieruchomości powinien powstrzymywać się od działań, które by zakłócały korzystanie z nieruchomości sąsiednich ponad przeciętną miarę wynikającą ze społeczno-gospodarczego przeznaczenia nieruchomości i stosunków miejscowych ${ }^{21}$. Tym samym wszelkie konflikty w sferze stosunków sąsiedzkich, należy rozwiązywać w świetle przepisów art. 140 i 144 ustawy z 23 kwietnia 1964 r. - Kodeks cywilny ${ }^{22}$. Właściciel nieruchomości znajdującej się w obszarze oddziaływania planowanego obiektu może domagać się poszanowania jego interesów wynikających z prawa do korzystania ze swojej własności, ale tylko w takim zakresie w jakim jest to uzasadnione. Nie chodzi zatem o wszelkie utrudnienia, jakie może przynieść planowane przedsięwzięcie, a jedynie o takie, które wiążą się z naruszeniem konkretnych przepisów szeroko rozumianego prawa budowlanego, prawa cywilnego, w głównej mierze tzw. prawa sąsiedzkiego, jak też uregulowań prawa konstytucyjnego ${ }^{23}$. Przesłanką naruszenia interesów osób trzecich jest przede wszystkim obiektywna ocena dotycząca przestrzegania obowiązujących przepisów prawa, a w szczególności wymagań technicznych oraz przepisów odnoszących się do budowy i utrzymania obiektów budowlanych. Przykładowo może mieć miejsce wtedy, gdy został naruszony bezpośredni interes prawny wykazujący, że dana inwestycja jest niezgodna z obowiązującymi przepisami prawnymi, naruszając $w$ ten sposób interes strony ${ }^{24}$. Omawiając powyższą zasadę nie sposób zwrócić uwagi na rodzące się wątpliwości interpretacyjne związane z określeniem wyrażenia "poszanowanie”, które wydaje się wyjątkowo nieprecyzyjne. Znacznie wyraźniej sprawę tę regulowano przed nowelizacją ustawy Prawo budowlane, dokonaną w ustawie z dnia 27 marca 2003 r. o zmianie ustawy - Prawo budowlane oraz o zmianie innych ustaw ${ }^{25}$. Kwestia ta wówczas dotyczyła "ochrony” uzasadnionych interesów osób trzecich, w którym wyraźnie określano rodzaje interesów osób trzecich podlegających ochronie w procesie budowlanym. Określenie „ochrona” wyrażało zabezpieczenie przed szkoda, niebezpieczeństwem. Natomiast „poszanowanie” wywodzi się z pojęcia „szacunek", mający zapewnić odpowiedni poziom zachowań o charakte-

${ }^{21}$ Wyrok NSA z 16 listopada 2004 r., OKS 786/04, ONSA 2005, nr 4, poz. 86; wyrok WSA w Łodzi z 8 grudnia 2005 r., II SA/Łd 852/05, LEX nr 876375; Wyrok SN z 10 lutego 2004 r., IV CK 454/02, LEX nr 175937.

${ }^{22}$ Ustawa z dnia 23 kwietnia 1964 r. - Kodeks cywilny, tekst jednolity, Dz. U. z 2016 r., poz. $380 \mathrm{z}$ późn. zm.

${ }^{23}$ Wyrok NSA z 11 marca 2014 r., II OSK 2474/12, LEX nr 1522466.

${ }^{24}$ Wyrok WSA w Warszawie z 18 października 2004 r., IV SA 4878/02, LEX nr 164448.

${ }^{25}$ Ustawa z dnia 27 marca 2003 r. o zmianie ustawy - Prawo budowlane oraz o zmianie innych ustaw, Dz. U. Nr 80, poz. 718. 
rze moralnym wobec interesów osób trzecich bez stosowania przymusu dla egzekwowania porządku prawno-administracyjnego ${ }^{26}$. Podkreśla się jednak, że ochrona uzasadnionych interesów osób trzecich nie może być rozumiana w sposób absolutny. Nie chodzi bowiem o wszelkie utrudnienia, jakie może przynieść planowane przedsięwzięcie, a jedynie o takie, które mogą dotyczyć naruszeń interesów prawnych, a nie faktycznych innych osób ${ }^{27}$.

Nieprecyzyjność wyrażeń „poszanowania”, jak również „uzasadnionych interesów", które zostały statuowane w nowelizacji, spotyka się z krytyką głosów w doktrynie i pytaniami o cel takiego zabiegu legislacyjnego $^{28}$. Wydaje się, że odpowiedzią na tak postawione pytanie może być intencja ustawodawcy, skłaniająca się do przeciwdziałania w blokowaniu przyszłych inwestycji. Uzasadniając ten punkt widzenia należy przypomnieć, że w poprzednio obowiązującym stanie prawnym ustawodawca także nie definiował pojęcia uzasadnionych interesów osób trzecich, ale w sposób precyzyjny określał szczegółowy zakres przedmiotowy tej ochrony i przy uwzględnieniu „szerokiego” pojęcia strony, stanowił nieuzasadnione pole do nadużywania przysługujących osobom trzecim uprawnień, które w istocie hamowały i zatrzymywały procesy inwestycyjno-budowlane ${ }^{29}$.

\section{Zasada ochrony interesów osób niepełnosprawnych}

Zasada ma na celu zapewnienie osobom niepełnosprawnym rzeczywistego równouprawnienia w życiu społecznym, określając przede wszystkim podstawowe warunki odnoszące się do należytej dostępności w korzystaniu z obiektów budowlanych. Gwarancja zapewnienia osobom niepełnosprawnym, w szczególności poruszających się na wózkach inwalidzkich, daje prawną ochronę do realizacji wymagań niezbędnych warunków do codziennego życia, pracy i dostępności do różnych obiektów, zwłaszcza użyteczności publicznej, budownictwa mieszkaniowego i wielorodzinnego. W celu ochrony tych osób, ustawodawca postanowił, że przepisy techniczno-budowlane będą przewidywały szereg warunków,

${ }^{26}$ E. Radziszewski, Prawo budowlane. Przepisy i komentarz, Warszawa 2005, s. 25-26.

27 Wyrok WSA w Kielcach z 20 marca 2015 r., II SA/Ke 1122/14, LEX nr 1669388.

${ }^{28}$ Z. Niewiadomski, [w:] Z. Niewiadomski (red.), Prawo budowlane. Komentarz, Warszawa 2006, s. 127-128.

29 Tak S. Serafin, Prawo budowlane. Komentarz, Warszawa 2006, s. 142-143. 
których celem będzie eliminowanie przeszkód dla osób niepełnosprawnych $^{30}$. Właściwe zapewnienie tej ochrony w praktyce, polega na uznaniu licznych wymagań w stosunku do obiektu budowlanego w zakresie wejść, dojazdów, pochylni, komunikacji wewnętrznej czy dźwigów osobowych, a także innych wymogów użytkowych, higieniczno-sanitarnych, zdrowotnych, bezpieczeństwa itp. ${ }^{31}$. Również instytucja odstąpienia od przepisów techniczno-budowlanych, doznaje wobec osób niepełnosprawnych ograniczenia w ogólnej dostępności dla użytkowników. W praktycznym znoszeniu barier architektonicznych dla tych osób, pomocne może się okazać także wieloletnie doświadczenie i wiedza medyczna, mimo ich braku w przepisach prawa budowlanego ${ }^{32}$.

\section{Zasada ochrony zabytków}

Prawo budowlane wypełnia funkcje ochronną wobec obiektów budowlanych wpisanych do rejestru zabytków oraz obiektów objętych ochroną konserwatorską. Realizacja ochrony zabytków dokonuje się $\mathrm{w}$ procesie projektowania i budowy, gdzie przepisy prawa budowlanego nie powinny naruszać przepisów odrębnych dotyczących zabytków na postawie miejscowego planu zagospodarowania przestrzennego. Ustawodawca nakłada obowiązek na uczestników procesu budowlanego ochrony dóbr kultury, która jako konstytucyjne chroniona ma pierwszeństwo przed prawem zabudowy nieruchomości przysługującemu właścicielo$\mathrm{wi}^{33}$. Ochronie zabytków stanowiących obiekty budowlane służą przepisy ustawy z dnia 23 marca 2003 r. o ochronie zabytków i opiece nad zabyt$\mathrm{kami}^{34}$. Wprowadzona $\mathrm{w}$ drodze tej regulacji ochrona zabytków, polega m.in. na zapobieganiu zagrożeniom mogącym spowodować uszczerbek

${ }^{30}$ Zadaniem M. Błażowskiego, wśród wartości chronionych w procesie budowlanym, należy zaliczyć dostępność obiektów budowlanych dla osób niepełnosprawnych. M. Błażowski, Ochrona wartości w procesie budowlanym, [w:] J. Zimmermann (red.), Wartości w prawie administracyjnym. V Krakowsko-Wrocławskie Spotkanie Naukowe Administratywistów, Warszawa 2015, s. 308-309.

31 S. Serafin, Prawo budowlane..., s. 140; Szerzej na ten temat: W. Szwajdler, T. Bąkowski, Proces inwestycyjno-budowlany. Zagadnienia administracyjno-prawne, Toruń 2004, s. 296-303.

${ }_{32}$ W. Korzeniewski, Przystosowanie budynków i pomieszczeń do potrzeb osób niepetnosprawnych, „Przedsiębiorca Budowlany” 1997, nr 11, s. 16-17.

${ }_{33}$ Wyrok NSA z 9 lutego.2005 r., OSK 49/05, niepubl.

${ }^{34}$ Ustawa z dnia 23 marca 2003 r. o ochronie zabytków i opiece nad zabytkami, tekst jednolity, Dz.U. z 2014, poz. 1446,z późn zm. 
dla wartości zabytków oraz sprawowania kontroli stanu ich zachowania i przeznaczenia. Ponadto obliguje właściciela lub posiadacza obiektu budowlanego stanowiącego zabytek do sprawowania opieki i prowadzenia prac konserwatorskich, restauratorskich i robót budowlanych, zabezpieczenie i utrzymanie zabytku oraz jego otoczenia. Wykonywanie wszelkich robót $\mathrm{w}$ obiekcie zabytkowym podlega $\mathrm{w}$ pełnym zakresie rygorom ustawy Prawo budowlane oraz obowiązkom wynikających z ustawy o ochronie zabytków i opiece nad zabytkami. Ochrona zabytkowych obiektów sprowadza się w procesie budowlanym do czuwania, by każde zamierzenia budowlane (remont, zmiana sposobu użytkowania, rozbiórka) były poprzedzone uzyskaniem przez inwestora odpowiedniej decyzji wojewódzkiego konserwatora zabytków.

\section{Zasada zgodności projektowania i budowania obiektów budowlanych}

Jednym z podstawowych elementów treści tejże zasady jest określenie nakazujące projektować i budować obiekt budowlany w sposób określony w przepisach ustawy Prawo budowlane, w tym techniczno-budowlanych oraz zgodnie z zasadami wiedzy technicznej, aby zapewnić spełnienie podstawowych wymagań dotyczących bezpieczeństwa konstrukcji, bezpieczeństwa pożarowego, bezpieczeństwa użytkowego, odpowiednich warunków higienicznych i zdrowotnych oraz ochrony środowiska, ochrony przed hałasem i drganiami, odpowiedniej charakterystyki energetycznej budynku oraz racjonalizacji użytkowania energii.

Przestrzeganie podstawowych przepisów ma na celu zapewnienie warunków użytkowych zgodnych z przeznaczeniem obiektu, w szczególności w zakresie zaopatrzenia $\mathrm{w}$ wodę i energię elektryczną, odpowiednio do potrzeb - w energię cieplną i paliwa, przy założeniu efektywnego wykorzystania tych czynników oraz usuwania ścieków, wody opadowej i odpadów.

Zasada zgodność projektowania i budowania obiektów budowlanych rozciąga się również na właściwe utrzymanie obiektów budowlanych, nakazując stosowanie właściwych przepisów techniczno-budowlanych zgodnie z zasadami wiedzy technicznej, w celu zapewnienia w przyszłości należytego stanu technicznego obiektu budowlanego oraz wszelkich warunków bezpieczeństwa przewidzianych w tych przepisach. 


\section{Zasada właściwego użytkowania obiektów budowlanych}

Zasada ta stanowi, że obiekt budowlany należy użytkować w sposób zgodny z jego przeznaczeniem i wymaganiami ochrony środowiska, które są uwzględnione $\mathrm{w}$ przepisach określających warunki techniczne, jakim powinny odpowiadać obiekty budowlane, jak też mogą wynikać z przepisów odrębnych, których przedmiotem jest ochrona środowiska ${ }^{35}$. Obowiązek użytkowania zgodnie z przeznaczeniem, należy interpretować jako użytkowanie obiektu do takich celów, które mogą wynikać z kilku elementów: 1) z charakteru danego obiektu budowlanego; 2) z aktu administracyjnego; 3 ) z aktu prawa miejscowego, czyli miejscowego planu zagospodarowania przestrzennego. W szczególnych przypadkach przeznaczenie obiektu może wynikać również z innych dokumentów, np. z projektu budowlanego czy oświadczenia woli właściciela obiektu ${ }^{36}$. Użytkowanie w zgodzie z przeznaczeniem może być także efektem zmiany sposobu użytkowania obiektu budowlanego, w szczególności przez podjęcie bądź zaniechanie w obiekcie budowlanym lub jego części działalności powodującej zmiany warunków bezpieczeństwa, ochrony środowiska lub wielkości bądź układu obciążeń. W celu właściwego użytkowania obiektów budowlanych należy przeprowadzać kontrole i poddawać ich ocenom przydatności do użytkowania. Niewłaściwe użytkowanie obiektu budowlanego może przyczynić się do szybszego zużycia technicznego obiektu.

35 Prawne instrumenty uwzględniające ochronę środowiska na etapie użytkowania obiektu budowlanego, polegające przede wszystkim na zapobieganiu lub ograniczeniu wprowadzania do środowiska substancji lub energii, zawiera ustawa z 27 kwietnia $2001 \mathrm{r}$. - Prawo ochrony środowiska.

${ }^{36}$ C. Woźniak, [w:] H. Kisilowska (red.), Prawo budowlane z umowami w działalności inwestycyjnej. Komentarz, Warszawa 2010, s. 292-293; Jak zauważa C. Woźniak, użyte przez ustawodawcę pojęcie użytkowanie obiektu budowlanego jest mylące w kontekście systemu polskiego prawa. Użytkowanie jest bowiem ograniczonym prawem rzeczowym polegającym na korzystaniu z rzeczy i pobieraniu pożytków z niej, w ramach zgody udzielonej przez właściciela rzeczy. Z tego wynika, że nie chodzi tutaj o użytkowanie w znaczeniu Kodeksu cywilnego, a po prostu korzystanie z obiektu. Tamże, s. 292. Zatem przez pojęcie użytkowania obiektu budowlanego, należy rozumieć wykorzystywanie obiektu do celów dla jakich powstał. Ponadto użytkowanie obiektu budowlanego obejmuje wszelkie działania niezbędne do ciągłego utrzymywania obiektu w stanie pełnej użyteczności zgodnie $\mathrm{z}$ jego przeznaczeniem. 


\section{Zasada należytego utrzymania obiektów budowlanych}

Zasada należytego utrzymania obiektu budowlanego oznacza utrzymywanie obiektu w należytym stanie technicznym i estetycznym, nie dopuszczając do nadmiernego pogorszenia jego właściwości użytkowych i sprawności technicznej, w szczególności w zakresie związanym z wymaganiami dotyczącymi: 1) spełnienia wymagań podstawowych w zakresie: bezpieczeństwa konstrukcji, bezpieczeństwa pożarowego, bezpieczeństwa użytkowania, odpowiednich warunków higienicznych i zdrowotnych oraz ochrony środowiska, a także odpowiedniej charakterystyki energetycznej budynku oraz racjonalizacji użytkowania energii; 2) zapewnienia warunków użytkowych zgodnych z przeznaczeniem obiektu;3) możliwości utrzymania właściwego stanu technicznego; 4) niezbędnych warunków do korzystania z obiektów przez osoby niepełnosprawne; 5) warunków bezpieczeństwa i higieny pracy; 6) ochrony ludności zgodnie z wymogami obrony cywilnej; 7) ochrony zabytków. Rozwinięcie tych wymogów następuje przede wszystkim w przepisach techniczno-budowlanych oraz w odrębnych przepisach dotyczących zarówno różnego rodzaju wpływu budownictwa na otoczenie, jak i oddziaływania na budownictwo ${ }^{37}$. W celu zapewnienia należytego utrzymania obiektu budowlanego, jego stan techniczny powinien być regularnie kontrolowany przez właściciela lub zarządcę obiektu budowlanego, zwłaszcza w zakresie oceny właściwości użytkowych i sprawności technicznej. Należy zaznaczyć jednak, że właściciel bądź zarządca obiektu budowlanego jest obowiązany dokonywać nie tylko tych czynności, które pozwalają utrzymać obiekt $\mathrm{w}$ stanie umożliwiającym prawidłowe z niego korzystanie, lecz także i tych, które wchodzą w zakres profilaktycznego zabezpieczenia obiektu budowlanego przed przewidywanym na wiele lat wpływem otoczenia $^{38}$.

Utrzymanie obiektów budowlanych to bardzo ważne społecznie i gospodarczo działania, dlatego w celu realizacji zasady należytego utrzymania obiektu budowlanego ustawodawca wprowadza szereg obowiązków o charakterze formalnym dla podmiotów zobowiązanych do stałego monitorowania stanu technicznego i estetycznego oraz podejmowania działań mających na celu usunięcie usterek i objawów zużycia, zarówno

37 E. Radziszewski, Budowlane ABC. Poradnik prawny inwestora i użytkownika, Warszawa 1995, s. 37.

${ }^{38}$ C. Woźniak, [w:] H. Kisilowska (red.), Prawo budowlane..., s. 296 i przywołany tam wyrok SN z 29 stycznia 2002 r., V CKN 690/00, LEX nr 54344. 
wynikających z naturalnego zużycia, jak i działań sił zewnętrznych ${ }^{39}$. Ich przeprowadzenie zapewnia racjonalną gospodarkę zasobami budowlanymi, ład budowlany i estetykę przestrzeni zabudowanej ${ }^{40}$.

Z powyższego widać, że zasada należytego utrzymania obiektu budowlanego, wzajemnie uzupełnia się z zasadą właściwego użytkowania obiektu budowlanego. Obie mają charakter norm ogólnych służących jako wytyczne do oceny funkcjonowania podmiotów odpowiedzialnych za prawidłowe wykorzystanie obiektów budowlanych ${ }^{41}$.

\section{Zasada racjonalnego użytkowania energii}

Zasada racjonalnego użytkowania energii w budynkach ma służyć podniesieniu standardu użytkowego budynków i przedłużenie ich trwałości. Racjonalizacja użytkowania energii jest jednym z podstawowych wymagań stawianych budynkom. Każdy budynek powinien spełniać wymagania ochrony cieplnej i w zależności od sytuacji, mieć potwierdzenie w odpowiednim świadectwie energetycznym ${ }^{42}$. Świadectwa te są narzędziem wspierającym poprawę efektywności energetycznej ${ }^{43}$.

Zgodnie z przepisami ustawy z dnia 20 maja 2016 r. o efektywności energetycznej $^{44} \mathrm{w}$ nowych oraz istniejących budynkach poddawanych przebudowie lub przedsięwzięciu służącemu poprawie efektywności energetycznej, które są użytkowane przez jednostki sektora finansów publicznych w rozumieniu ustawy z dnia 27 sierpnia 2009 r. o finansach

${ }^{39}$ M. Substyk, Utrzymanie i kontrola okresowa obiektów budowlanych, Gdańsk 2012, s. 28.

${ }^{40}$ T. Biliński, E. Kucharczyk, Prawo budowlane..., s. 18.

${ }^{41}$ C. Woźniak, [w:] H. Kisilowska (red.), Prawo budowlane..., s. 292.

${ }^{42}$ T. Biliński, Uwagi krytyczne o budownictwie, „Przegląd Budowlany” 2012, nr 1, s. 24.

${ }^{43}$ Polska w celu podniesienia poprawy efektywności energetycznej, opracowała programy w czterech sektorach: mieszkalnictwie, usługach, przemyśle oraz transporcie. Środkiem w mieszkalnictwie jest utworzenie Funduszu Termomodernizacji i Remontów określonego w ustawie z 21 listopada 2008 r. o wspieraniu termomodernizacji i remontów, Dz.U. Nr 223, poz. 1459 z późn. zm.. Został on skierowany do właścicieli budynków wielorodzinnych oraz właścicieli i zarządców innych budynków mieszkalnych i zbiorowego zamieszkania, jak również jednostek samorządu terytorialnego z wyłączeniem zakładów budżetowych. R. Bielaszka, Kształtowanie polskich rozwiąań prawnych przez Unię Europejska w zakresie efektywności energetycznej, "Zeszyty Naukowe Uniwersytetu Rzeszowskiego Prawo" 2013, nr 13, s. 190-191.

${ }^{44}$ Ustawa z dnia 20 maja 2016 r. o efektywności energetycznej, Dz. U. z 2016 r., poz. 831. 
publicznych ${ }^{45}$, zaleca się stosowanie urządzeń wykorzystujących energię wytworzoną z odnawialnych źródłach energii, a także technologie mające na celu budowę budynków o wysokiej charakterystyce energetycznej. W przypadku robót budowlanych polegających na dociepleniu budynku, obejmujących ponad $25 \%$ powierzchni przegród zewnętrznych tego budynku, należy spełnić wymagania minimalne dotyczące energooszczędności i ochrony cieplnej dla przebudowy budynku. Wymagania w zakresie ochrony cieplnej dla budynków są zawarte w przepisach techniczno-budowlanych, których celem jest ograniczenie zużywanej energii $\mathrm{w}$ użytkowanych budynkach na racjonalnie niskim poziomie. Ponadto przepisy dotyczące oszczędności energii w budynkach obejmują również zagadnienia ochrony pomieszczeń przed przegrzaniem w okresie letnim. Ustanowione regulacje prawne dotyczące ochrony cieplnej budynków stanowią istotną determinantę współcześnie pojmowanego procesu budowlanego, obejmującego utrzymanie techniczne obiektów budowlanych ${ }^{46}$.

\section{Zasady wiedzy technicznej}

Przyjmuje się, że zasady wiedzy technicznej wynikają z praktyki budowlanej i wcześniejszych doświadczeń uczestników procesów budowlanych i producentów wyrobów budowlanych, jak również z należytej staranności ${ }^{47}$. Zasady wiedzy technicznej tworzą w rzeczywistości normy zgodnego z osiągnięciami nauk empirycznych postępowania, przez co wywierają znaczny wpływ na proces budowlany. Zawarte $\mathrm{w}$ prawie budowlanym odesłania do zasad wiedzy technicznej pozwala prawidłowo uregulować zachodzące w procesie budowlanym wysoce specjalistyczne stosunki techniczno-budowlane. Oznacza to, że choć w procesie stosowania prawa budowlanego zarówno uczestnicy procesu budowla-

${ }^{45}$ Ustawa z dnia 27 sierpnia 2009 r. o finansach publicznych, tekst jednolity, Dz. U. z 2016 r., poz. 1870.

${ }_{46}$ T. Biliński, Struktura i uwarunkowania wspótczesnego procesu inwestycyjno-budowlanego, „Przegląd Budowlany” 2010, nr 11, s. 50.

${ }^{47} \mathrm{~J}$. Czupajłło, Założenia projektowe niezgodne z zasadami wiedzy technicznej jako częsty powód braków wykonawczych, „Inżynier Budownictwa” 2013, nr 12, s. 37; Zdaniem W. Ciołka zasady wiedzy technicznej to coś znacznie szerszego niż tylko praktyka budowlana, sztuka budowlana czy zasady rzemiosła. Jak wskazuje, byłoby pożądane, aby w ustawie znalazła się legalna definicja terminu „zasady wiedzy technicznej”. Szerzej na ten temat: :W. Ciołek, Co oznacza termin „zasady wiedzy technicznej”, „Inżynier Budownictwa” 2014, nr 3, 37-39. 
nego, jak i właściwe organy administracji publicznej działają w granicach wyznaczonych przez przepisy prawa, to przepisy te nakładają obowiązek bezpośredniego odnoszenia się do wiedzy technicznej w budownictwie ${ }^{48}$. Materię zasad wiedzy technicznej charakteryzuje nie tylko złożoność różnych stanów faktycznych, ale i wynikający z postępu technicznego dynamizm ich rozwoju ${ }^{49}$. Wprowadzenie zasad wiedzy technicznej do zasad użytkowania i utrzymania obiektów budowlanych powoduje konieczność ich uwzględniania przy interpretacji innych szczegółowych przepisów ustawowych, wykonawczych, a nawet przepisów stosowanych posiłkowo. W rzeczywistości istota stosowania zasad wiedzy technicznej polega na ich umiejętnym wykorzystaniu w sytuacji braku odpowiedniej normy prawnej $j^{50}$.

\section{Zakończenie}

W konkluzji można stwierdzić, że prawo budowlane w swej warstwie materialnej, jawi się jako zespół norm powiązanych przez pewną wspólną ideę wykonywania działalności budowlanej i użytkowej. Ta elementarna spójność prawa budowlanego, wyraża się w przyjęciu w sposób wyraźny lub domniemany pewnych zasad, jakim podlega treść i struktura tego prawa. Cechą zasad prawa budowlanego jest różny stopień ich ogólności, mimo to można je ułożyć w pewne logicznie przeplatające się wzajemnie ciągi, wyrażające dążność do zaspokojenia z jednej strony interesu publicznego, a z drugiej strony do ochrony praw, wolności, interesów jednost$\mathrm{ki}^{51}$. Nie ulega wątpliwości, że zasady prawa budowlanego wskazuja, że głównym ich celem jest stworzenie podstaw dla urzeczywistnienia przez władze publiczną interesu publicznego, niekiedy kosztem wolności i interesów jednostek. Niektóre zasady wykazują się tendencją do stałego rozszerzania i wzmacniania, natomiast inne zasady utrzymują się jako pewne

${ }^{48}$ H. Kisilowska, D. Sypniewski, Nauka materialnego prawa administracyjnego a nauki techniczne w sferze badań nad administracja publiczna na przyktadzie Prawa budowlanego, [w:] S. Wrzosek, M. Domagała, J. Izdebski, T. Stanisławski (red.), Współzależność dyscyplin w sferze administracji publicznej, Warszawa 2010, s. 560.

49 S. Serafin, Zagadnienia techniczne w prawie budowlanym, Warszawa 2005, s. 101-102.

50 Tamże, s. 103.

51 A. Chełmoński, Zasady publicznego prawa gospodarczego, [w:] A. Śmieja (red.), Zasady prawa gospodarczego. Materiały z Konferencji naukowej zorganizowanej przez Katedre Prawa Gospodarczego Akademii Ekonomicznej we Wrocławiu, Sobótka 10-12 września 1998 r., Wrocław 1999, s. 53. 
trwałe zjawiska w strukturze prawa budowlanego, które przejawiają się w szczególniejszych normach, w postaci nakazów, zakazów, zgłoszeń, pozwoleń, czy także $\mathrm{w}$ formie różnego nadzoru administracyjnego. Jednakże nie sposób nie stwierdzić, że naczelna zasada wolności budowlanej dotyczy właśnie ochrony jednostki przed nadmiernym władztwem organów administracji publicznej, przez określenie granic i sposobów jego użycia.

Słowa kluczowe: Prawo budowlane, budowa, obiekt budowlany

\section{Bibliografia}

Bielaszka R., Ksztattowanie polskich rozwiazań prawnych przez Unię Europejska w zakresie efektywności energetycznej, "Zeszyty Naukowe Uniwersytetu Rzeszowskiego Prawo" 2013, nr 13.

Biliński T., Struktura i uwarunkowania wspótczesnego procesu inwestycyjno-budowlanego, „Przegląd Budowlany” 2010, nr 11.

Biliński T., Kucharczyk E., Prawo budowlane z omówieniem i komentarzem, Zielona Góra 2013.

Błażowski M., Ochrona wartości w procesie budowlanym, [w:] J. Zimmermann (red.), Wartości w prawie administracyjnym. V Krakowsko-Wrocławskie Spotkanie Naukowe Administratywistów, Warszawa 2015.

Chełmoński,A. Zasady publicznego prawa gospodarczego, [w:] A. Śmieja (red.), Zasady prawa gospodarczego. Materiaty z Konferencji naukowej zorganizowanej przez Katedrę Prawa Gospodarczego Akademii Ekonomicznej we Wroctawiu, Sobótka 10-12 września 1998 r., Wrocław 1999.

Ciołek W., Co oznacza termin "zasady wiedzy technicznej”, „Inżynier Budownictwa" 2014, nr 3.

Czarnik Z., Miejscowy plan zagospodarowania przestrzennego jako podstawa wykonywania własności nieruchomości, "Zeszyty Naukowe Sądownictwa Administracyjnego" 2006, nr 2.

Czupajłło J., Założenia projektowe niezgodne z zasadami wiedzy technicznej jako częsty powód braków wykonawczych, „Inżynier Budownictwa” 2013, nr 12.

Hauser R., Niewiadomski Z., Konstytucyjne aspekty regulacji procesu inwestycyjno budowlanego, „Państwo i Prawo” 2015, nr 6.

Jakimowicz W., Konstrukcja i istota wolnościowego prawa do zabudowy, „Samorząd Terytorialny" 2005, nr 6.

Kisilowska H., Sypniewski D., Nauka materialnego prawa administracyjnego a nauki techniczne w sferze badań nad administracja publiczna na przykładzie Prawa budowlanego, [w:] M. Domagała, J. Izdebski, T. Stanisławski (red.), Wspótzależność dyscyplin w sferze administracji publicznej, Warszawa 2010. 
Kostka Z., Prawo budowlane. Komentarz, Gdańsk 2005.

Kordela M., Zasady prawa jako normatywna postać wartości, „Ruch Prawniczy, Ekonomiczny i Socjologiczny" 2006, nr 1.

Korzeniewski W., Przystosowanie budynków i pomieszczeń do potrzeb osób niepełnosprawnych, „Przedsiębiorca Budowlany” 1997, nr 11.

Leoński Z., Zasada wolności budowlanej i jej administracyjnoprawne ograniczenia, [w:] Z. Leoński (red.), Rola materialnego prawa administracyjnego a ochrona praw jednostki, Poznań 1998.

Leoński Z., Zasada wolności budowlanej i jej administracyjnoprawne ograniczenia, [w:] H. Bauer, R. Hendler, P. M. Huber, B. Popowska, T. Rabska, M. Szewczyk (kom. red.), Kierunki rozwoju prawa administracyjnego. Podstawowe zagadnienia prawa budowlanego i planowania przestrzennego. Dziesiate Niemiecko-Polskie kolokwium prawników administratywistów. Poznań 8-12 września 1997 r. Referaty i głosy w dyskusji, Poznań 1999.

Leoński Z., Szewczyk M., Kruś M., Prawo zagospodarowania przestrzeni, Warszawa 2012.

Leszczyński L, Maroń G., Pojęcie i treść zasad prawa oraz generalnych klauzul odsyłających. Uwagi porównawcze, "Annales UMCS sectio G 2013”, vol. LX, 1.

Majchrzak B., Procedura zgłoszenia robót budowlanych, Warszawa 2008.

Niewiadomski Z., [w:] Z. Niewiadomski (red.) Prawo budowlane. Komentarz, Warszawa 2006.

Radziszewski E., Budowlane ABC. Poradnik prawny inwestora $i$ użytkownika, Warszawa 1995.

Radziszewski E., Prawo budowlane. Przepisy i komentarz, Warszawa 2005.

Serafin S., Zagadnienia techniczne w prawie budowlanym, Warszawa 2005.

Serafin S., Prawo budowlane. Komentarz, Warszawa 2006.

Substyk M., Utrzymanie i kontrola okresowa obiektów budowlanych, Gdańsk 2012.

Sypniewski D., Deregulacja procesu inwestycyjno-budowlanego. Ograniczenie reglamentacji robót budowlanych, "Przegląd Prawa Publicznego" 2013, nr 2.

Szwajdler W., Bąkowski T., Proces inwestycyjno-budowlany. Zagadnienia administracyjno-prawne, Toruń 2004.

Witkowski Z., [w:] Z. Witkowski (red.), Prawo konstytucyjne, Toruń 2006.

Woźniak C., [w:] H. Kisilowska (red.), Prawo budowlane z umowami w działalności inwestycyjne. Komentarz, Warszawa 2010.

Wronkowska S, Zieliński M., Ziembiński Z., Zasady prawa. Zagadnienia podstawowe, Warszawa 1974.

Zwolak S., O wolności budowlanej w orzeczeniu polskiego Trybunału Konstytucyjnego w sprawie pozwolenia na budowę (Kp 7/09), "Ius et Administratio” 2014, nr 2. 


\section{THE PRINCIPLES OF CONSTRUCTION LAW}

\section{$\mathrm{S} \mathbf{u} \mathbf{m} \mathbf{m}$ a $\mathbf{r}$}

The subject of the principles of construction law is the starting point for the detailed considerations regarding particular legislation and the correctness of decisions maturing in the construction process. Separation of the principles of construction law aims not only impact on the behavior of certain actors towards further specific behaviors, but what it's worth noting, are used to introduce specific values, which are subject to special protection in the construction process.

Key words: construction law, construction, building object

\section{ПРИНЦИПЫ СТРОИТЕЯЬНОГО ПРАВА}

$$
\text { P е } 3 \text { ю м е }
$$

Принципы строительного права являются отправной точкой для подробного рассмотрения конкретных законов и правильности решений в процессе строительства. Целью отделения принципов строительного права есть не только влияние на поведение отдельных субъектов в направлении принятия определенных поведений, но что стоит отметить, использование для введения определенных значений, которые являются объектом особой защиты в процессе строительства.

Кдючевые слова: строительное право, строительство, строительный объект 